GLUCOCORTICOIDs are potent inhibitors of in flam matory processes and are widely used in the treatment of asth $m$. The anti-inflammatory effects are mediated either by direct binding of the glucocorticoid/glucocorticoid receptor complex to glucocorticoid responsive elements in the promoter region of genes, or by an interaction of th is complex with other transcription factors, in particular activating protein-1 or nuclear factor $-\kappa B$. Glucocorticoids inhibit many inflammation-associated molecules such as cytokines, chemokines, arachidonic acid metabolites, and adhesion molecules. In contrast, anti-inflammatory mediators often are up-regulated by glucocorticoids. In vivo studies have shown that treatment of asthmatic patients with inhaled glucocorticoids inhibits the bronchial inflammation and simultaneously improves their lung function. In this review, our current knowledge of the mechanism of action of glucocorticoids and their anti-inflam matory potential in asthma is described. Since bronchial epithelial cells may be important targets for glucocorticoid therapy in asthma, the effects of glucocorticoids on epithelial expressed inflammatory genes will be emphasized.

Key words: Glucocorticoids, Asthma, Bronchial epithelial cells, Inflammation

\section{Glucocorticoids: mechanisms of action and anti-inflammatory potential in asthma}

\author{
V. H. J. van der Velden
}

Department of Immunology, Erasmus University, PO Box 1738, 3000 DR Rotterdam, The Netherlands

Tel: $(+31) 104087192$

Fax: (+31) 104367601

Email: vandervelden@immu.fgg.eur.nl

\section{Introduction}

Glucocorticoids are hormones synthesized in the adrenal cortex and secreted into the blood, where the levels of glucocorticoids fluctuate in a circadian mode. In humans, the naturally occurring glucocorticoid is hydrocortisone (cortisol), which is synthesized from its precursor cortisone.

The beneficial effects of glucocorticoids in asthmatic patients were first described in $1950 .{ }^{1}$ Since then on, many studies have focused on the therapeutic potential of glucocorticoids. Several synthetic glucocorticoids, much more potent than cortisol and without the unwanted mineralocorticoid side effects, have been developed. Now adays, glucocorticoids are powerful agents in the treatment of inflammatory diseases and are by far the most effective antiinflammatory drugs used in the treatment of asthma.

\section{Mechanism of Action}

Although glucocorticoids have been known for a long period of time, their precise mechanism of action is still not completely understood. However, recent studies have increased our understanding of their complex mechanisms of action.

\section{Glucocorticoid receptor}

To exert their effects, glucocorticoids need to bind to a specific cytoplasmic glucocorticoid receptor (GR). Almost all cells of the body express the GR, but the number of receptors may vary be tween different cell types. ${ }^{2}$ Cloning of the GR has revealed that the GR consists of approximately 800 amino acid residues, and that certain areas of the molecule show homology with other steroid receptors, receptors for thyroid hormones, and receptors for retinoic acid. ${ }^{3-7}$ All members of the nuclear hormone receptor family share a characteristic three-domain structure, first described for the human GR. The C-terminal domain is equal in size in all nuclear receptors studied (about 250 amino acids) and its main function is to bind the steroid. ${ }^{8}$ It also contains the binding sites for the heat shock proteins (hsp) 90. ${ }^{9,10}$ Removal of the steroidbinding domain results in a constitutively active GR molecule, indicating that this part of the molecule acts as a repressor of the transcription-activation function. The most conserved central domain is involved in direct binding of the receptor to DNA. It contains two distinct loops of protein, each bound at their base via four cysteine residues to a single zinc ion, the so-called zinc fingers. ${ }^{11}$ These zinc clusters are involved in binding of the GR to the major groove of the DNA double helix and play a role in dimeriza- 
tion of two GR molecules. ${ }^{12,13}$ In addition, the central DNA-binding domain has a transcription-activation function. ${ }^{4,14}$ The steroid-binding and DNA-binding domains are separated by the 'hinge-region', which contains sequences that are important for nuclear translocation and dimerization. ${ }^{9,10}$ The N-terminal domain is extremely variable in size (24-600 amino acids). Its precise role is still uncertain, but it is required in transcriptional activation. ${ }^{15}$

Two different forms of the human GR have been described. ${ }^{3,16}$ These tw o highly homologous is oforms, termed GR $\alpha$ and GR $\beta$, are generated by alternative splicing of the human GR pre-mRNA. The GR $\beta$ isoform differs from the GR $\alpha$ isoform only in its C-terminal domain, in which the last 50 amino acids of the latter are replaced by a unique 15 amino acid sequence. However, this replacement has dramatic functional consequences, since the GR $\beta$ isoform is unable to bind glucocorticoids and to transduce ligand-dependent transactivation. However, the physiological significance of the GR $\beta$ isoform remains questionable, since some recent studies indicate that this form is not conserved among species and no dominant negative inhibition of GR $\alpha$ activity could be found. ${ }^{17,18}$ Nevertheless, abundant ex pression of GR $\beta$ protein can be found in the epithelial cells lining the terminal bronchioli of the lung. ${ }^{19}$

The expression of the GR may be regulated by numerous factors either at the transcriptional, translational or post-translational level. ${ }^{20,21}$ Glucocorticoids have been shown to down-regulate the expression of the GR, both in vitro and in vivo. ${ }^{22,23}$ In contrast, inflammatory mediators like interleukin (IL)-1 $\beta$, IL 4 , tumour necrosis factor (TNF)- $\alpha$, lipopolysaccharide (LPS) and interferon (IFN) $-\gamma$ have been shown to increase glucocorticoid binding in vitro..$^{24-28}$ How ever, the increase in GR numbers may be accompanied by a reduced affinity for glucocorticoids. ${ }^{24,28}$ Analysis of GR localization in normal and asthmatic lung has not revealed differences in the level or sites of GR expression. ${ }^{29}$

\section{Regulation of gene transcription}

In the absence of glucocorticoids, the GR is present in the cytoplasm of the cell as a hetero-oligomer consisting of the GR itself, two molecules of hsp 90, one molecule hsp 70, and one molecule of hsp 56 (which probably does not interact with the GR itself, but interacts with hsp 90)..$^{30-34}$ Glucocorticoids enter the cytoplasm of the cell by passive diffusion through the cell membrane. In the cytoplasm they bind to the GR complex, which subsequently undergoes conformational changes, resulting in the dissociation of the hsp 90 and hsp 56 molecules. Upon this activation, the glucocorticoidGR complex passes the nuclear membrane, enters the nucleus, and the hsp 70 molecule is dissociated.

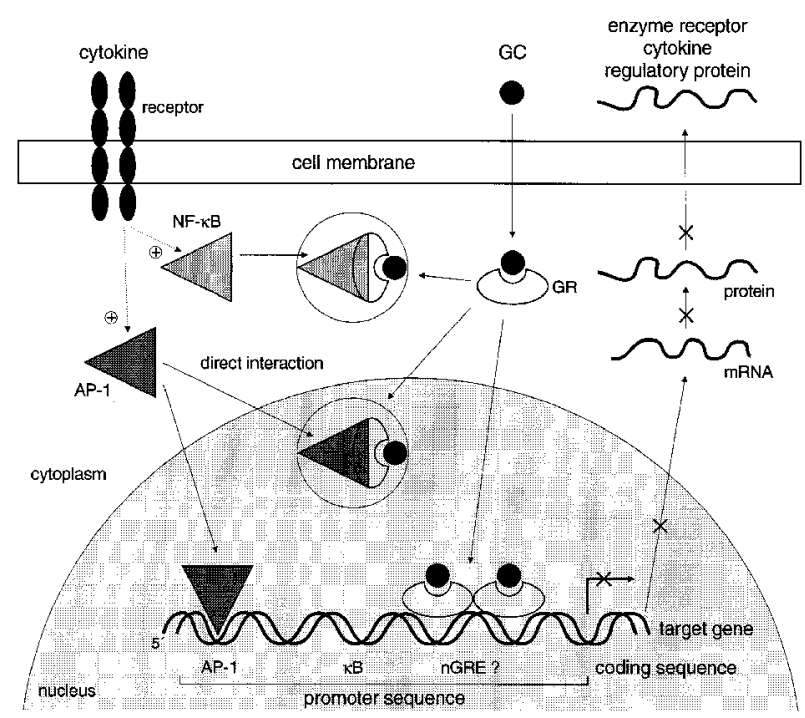

FIG. 1. Schematic representation of the cellular events after administration of glucocorticoids (adapted from Ref. 39).

Furthermore, in the nucleus liganded GR form homodimers (Fig. 1).

Within the nucleus, the GR homodimers may regulate gene transcription in several ways: (1) via binding of the glucocorticoid-GR complex to specific DNA sequences, the reby directly activating or repressing genes; (2) via interaction with other transcription factors; and (3) via modulating the stability of specific mRNA molecules. ${ }^{35-39}$

\section{Binding to DNA sequences}

Several steroid-responsive genes contain glucocorticoid responsive elements (GRE) in their promoter region. ${ }^{35,40}$ Binding of GR homodimers to GRE may either result in transcriptional activation of the gene (via a positive GRE) or repression of the gene (via a negative GRE) (Fig. 1). The consensus sequence for (positive) GRE is the palindromic 15-base-pair sequence GGTACAnnn TGTTCT, whereas the negative GRE has a more variable sequence. ${ }^{36}$ The rate of transcriptional regulation of steroid-responsive genes is dependent on both the numbers of GRE, the affinity of the glucocorticoid-GR complex to the GRE, and the position of the GRE relative to the transcriptional start site. Binding of the complex to GRE may result in conformational changes in the DNA and exposure of previously masked areas, resulting in increased binding of other transcription factors. ${ }^{41-44}$

\section{Interaction with other transcription factors}

Many steroid-responsive genes do not have GRE in their promoter region. However, binding sites for other transcription factors, including nuclear factor (NF) $-\kappa \mathrm{B}$, activating prote in (AP) -1 , and cAMP-responsive element binding protein (CREB), often can be found. ${ }^{45}$ 
AP-1, which is a dimer of two proto-oncogenes (members of the c-jun and c-fos family), ${ }^{46,47}$ is involved in the regulation of several genes, including adhesion molecules and cytokines (reviewed in Ref. 47). Direct protein-protein interaction between AP-1 and the glucocorticoid-GR complex results in recip rocal repression of one another's transcriptional activation by preventing binding of the AP-1 and glucocorticoid-GR complex to AP-1 sites and GRE, respectively (Fig. 1). ${ }^{37,48,49}$

Comparable to AP-1, NF- $\mathrm{B}$ (a hete rodimer of p50 and p65 subunits ${ }^{50,51}$ ) regulates the transcription of several genes involved in inflammatory reactions. ${ }^{50,52,53}$ In unstimulated cells, NF-KB is retained in the cytoplasm of the cells through the interaction $w$ ith the inhibitors I $\mathrm{I} B \alpha$ and $I \kappa B \beta .{ }^{54-56}$ Upon cell stimulation, for example by IL-1 $\beta$ or TNF- $\alpha$, I $\mathrm{B}$ are rapidly phosphorylated, ubiquitinated, and consequently proteolysed. ${ }^{53,57}$ The liberated NF-KB dimers translocate to the nucleus where they can activate target genes. Glucocorticoids may inhibit NF- $\kappa$ B-stimulated genes by a direct interaction between the glucocorticoid-GR complex and the p65 subunit of NF- $\mathrm{B}$, resulting in transrepression (Fig. 1). ${ }^{51,55,58,59}$ Furthermore, glucocorticoids may indirectly antagonize NF- $\mathrm{B}$ mediated transcription by up-regulating the synthesis of the

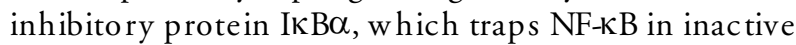
cytoplasmic complexes. ${ }^{39,54,55}$ A large number of immunoregulatory genes, whose expression is induced by a variety of pro-inflammatory mediators, contain NF- $\mathrm{KB}$ sites in their promoters/regulatory regions. The refore, it is no wonder that glucocorticoids have been found to prevent the expression of these genes, including those coding for IL-1 $\beta$, IL-2, IL-6, IL-8, monocyte chemoattractant protein (MCP)-1, RANTES (Regulated upon Activation, Normal T cell Expressed, and presumably Secreted), granulocyte macrophage colony-stimulating factor (GM-CSF), the IL-2 receptor, intercellular adhesion molecule (ICAM)-1, and E-selectin (reviewed in Ref. 45). Probably, interactions between glucocorticoids and NF-KB or AP-1 will explain most of the anti-inflammatory and immunosuppressive activities of glucocorticoids.

An interaction between CREB and the glucocorticoid-GR complex has also been suggested. ${ }^{60,61}$ $\beta$-agonists, which are used as bronchodilators in the treatment of asthma, increase cAMP formation and subsequently activate CREB. The refore, simultaneous treatment of asthmatic patients with glucocorticoids and $\beta$-agonists may result in reduced responsiveness of the airways for steroids. ${ }^{61-63}$

\section{Modulation of $m$ RNA stability.}

A third mechanism by which glucocorticoids may regulate the synthesis of proteins is via enhanced transcription of specific ribonucleases which are able to degrade mRNA containing constitutive AU-rich sequences in the untranslated $3^{\prime}$-region. ${ }^{64}$ Such gluco-
Table 1. Influence of glucocorticoids on the synthesis of proteins with inflammatory effects by bronchial epithelial cells

Protein

Glucocorticoid effect

Cytokines
IL-1 $\beta$, IL-6, IL-11, TNF- $\alpha$, GM-CSF
IL-10, LIF
G-CSF
Chemokines
MCP-1, eotaxin, IL-8, RANTES, MIP-1 $\alpha$
Receptors
NK, GR
IL-1R II, IL-6R, $\beta_{2}$-adrenergic receptor
Enzymes
iNOS, COX-2, cPLA 2
NEP
Adhesion molecules
ICAM-1
Inhibitory proteins
LC-1
IL-1RA type I, SPLI

LC-1

corticoid-mediated modulation of post-translational events (resulting in decreased mRNA stability and reduced half-life time) has been observed for IL-1 $\beta$, IL6 and GM-CSF. 65,66

\section{Glucocorticoid Regulated Genes}

Glucocorticoids are able to modulate the transcription of a variety of genes, including cytokines and chemokines, receptors, enzymes, adhesion molecules, and inhibitory proteins (Table 1$)$. Since epithelial cells may be one of the most important targets for glucocorticoid therapy in asthma, the effects of glucocorticoids on epithelial expressed inflammatory genes will be emphasized in this review.

\section{Cytokines and chemokines}

Glucocorticoids inhibit the transcription of most cytokines and chemokines that are relevant in as th ma, including IL- $1 \beta$, TNF- $\alpha$, GM-CSF, IL-3, IL- 4 , IL-5, IL-6, IL8, IL-11, IL-12, IL-13, RANTES, e otaxin, and macrophage inhibitory protein (MIP)- $1 \alpha .^{45,66}$ In general, reduced synthesis of these mediators may result in a decreased recruitment and activation of leukocytes, also indirectly due to effects on adhesion molecules and cell survival. Since many cytokine gene promoters do not contain a negative GRE, the effects of glucocorticoids on cytokine and chemokine production are probably mediated via an effect on a critical transcription factor (especially NF-KB and AP-1). ${ }^{67}$ Cross-signalling between NF-кB and AP-1 with glucocorticoid/GR complex have indeed been demonstrated in bronchial epithelial cells. ${ }^{67}$ 
Bronchial epithelial cells are capable of producing a varie ty of cytokines and chemokines that may contribute to the initiation and perpetuation of airway inflammation. Several studies have shown that cytokine-induced expression of eotaxin, IL-6, IL-8, GMCSF, and RANTES can be diminished by glucocorticoids in vitro. ${ }^{68-76}$ In contrast, glucocorticoids did not modulate the secretion of G-CSF by human bronchial epithelial cells. ${ }^{76}$ In vivo studies have show $n$ that treatment with inhaled steroids decreases both the expression of GM-CSF, ${ }^{77}$ IL- $1 \beta,{ }^{78}$ IL- $8,{ }^{79}$ and RANTES $^{80}$ by the bronchial epithelium, together with the number of activated eosinophils in the epithelium.

\section{Receptors}

Glucocorticoids may modulate the expression of several receptors. The expression of the neurokinin $(\mathrm{NK})_{1}$ receptor, which mediates many effects of substance P (SP) in the airways and is believed to be up-regulated in asthma, ${ }^{81}$ is down-regulated by glucocorticoids. ${ }^{82}$ Since the $\mathrm{NK}_{1}$ receptor gene promoter region has no GRE but has an $\mathrm{AP}-1$ response element, this effect probably will be mediated via an interaction of the glucocorticoid-GR complex with AP-1.

In contrast to $\mathrm{NK}_{1}$ receptors, expression of the $\beta_{2}$-adrenergic receptor is increased by glucocorticoids. ${ }^{83}$ Since the human $\beta_{2}$-adrenergic receptor gene contains three potential GRE, this effect of glucocorticoids probably is a direct one. ${ }^{83}$ Up-regulation of $\beta_{2}$-adrenergic receptors by glucocorticoids may be relevant in asthma as it may prevent downregulation in response to prolonged treatment with $\beta_{2}$-agonis ts. ${ }^{84}$

The IL-1 receptor type II, which functions as a decoy receptor, ${ }^{85}$ may also be up-regulated by glucocorticoids, thereby reducing the functional activity of IL-1 agonists. ${ }^{86,87}$ Soluble TNF-receptor type I (p55) release by human bronchial epithelial cells, both constitutive as well as IL-1 $\beta$-induced, has been shown to be reduced by glucocorticoids. ${ }^{88}$ In contrast, glucocorticoids up-regulate the expression of IL-6 receptors in rat hepatoma and human epithelial cells. ${ }^{89,90}$ Thus far little is know $\mathrm{n}$ about this process in human bronchial epithelial cells, which constitutively express these receptors. ${ }^{91}$

Glucocorticoids also modulate the expression of their own receptor. In a recent study it was shown that expression of the $\alpha$-form (but not the $\beta$-form) of the GR in human bronchial epithelial cells was downregulated in healthy subjects after 4 weeks of budesonide inhalation. ${ }^{23}$

\section{Enzymes}

Glucocorticoids inhibit the synthesis of several inflammatory mediators implicated in the pathogene- sis of asthma through an inhibitory effect on enzyme induction. The synthesis of inducible nitric oxide synthase (iNOS) by human airway epithelial cells is inhibited by glucocorticoids, both in vitro and in vivo. ${ }^{92-94}$ This effect seems to be mediated via inactivation of NF-kB. ${ }^{95,96}$ Since nitric oxide (NO) may contribute to skewing of Th lymphocytes towards a Th2 phenotype, thereby promoting $\operatorname{IgE}$ production and eosinophil recruitment, inhibition of iNOS may be of importance in anti-inflammatory therapy in as thma. ${ }^{97}$

Glucocorticoids also inhibit the gene transcription of a cytosolic form of phospholipase $A_{2}$ induced by cytokines $^{98}$ and inhibit the gene expression of cyclooxygenase-2, resulting in reduced formation of prostaglandins and thromboxanes. ${ }^{99}$

In contrast to the enzymes mentioned above, glucocorticoids have been shown to increase the expression of neutral endopeptidase (NEP), ${ }^{100-102}$ thereby potentially limiting neurogenic inflammatory responses. ${ }^{103}$ In accordance with these results, it was found that the expression of NEP on bronchial epithelial cells was higher in asthmatics treated with steroids compared with nonsteroid-treated asth matics. ${ }^{104}$

\section{Endothelins}

Endothelins are a family of highly homologous 21 -amino acid peptides, characterized by two intrachain disulphide chains, a hairpin loop consisting of polar amino acids, and a hydrophobic C-terminal chain. ${ }^{105}$ Human bronchial epithelial cells have been shown to produce ET-1, ${ }^{106-108}$ which promotes the proliferation of smooth muscle cells, is a potent constrictor of both vascular and non-vascular smooth muscle cells, increases the secretion of mucus, and may activate inflammatory cells. ${ }^{105,107,109}$ ET-1 also stimulates collagen gene expression and through its inhibitory actions on collage nase will promote airway wall collagen deposition, thereby contributing to airway wall thickening which underlies bronchial hyperresponsiveness. ${ }^{110-112}$ Increased levels of ET1-immunoreactivity were detected in airway epithelium and vascular endothelium of bronchial biopsy specimens from nonsteroid-treated asthmatics compared with healthy subjects. ${ }^{106,113,114}$ In contrast, no increased ET-1 expression was found in the bronchial epithelium of asthmatic patients treated with glucocorticoids. ${ }^{115}$

\section{Adhesion molecules}

Adhesion molecules play an important role in the recruitment of inflammatory cells to the inflammatory locus. Expression of adhesion molecules on endothelial, epithelial or inflammatory cells is often 
induced by cytokines, whereas glucocorticoids reduce surface expression of adhesion molecules. This effect may be due either to inhibition of cytokine synthesis or to a direct effect of glucocorticoids on adhesion molecule gene transcription. It has been shown that the expression of ICAM-1, endothelial leukocyte adhesion molecule (ELAM)-1, and E-selectin is down-regulated by ste roids. ${ }^{116}$ Basal and cytokinestimulated ICAM-1 expression on human bronchial epithelial cell lines is inhibited by glucocorticoids. ${ }^{17,118}$ However, inhaled glucocorticoids did not modulate ICAM-1 expression by bronchial epithelial cells from asthmatics in vivo. ${ }^{119}$

Eosinophil adhesion to cytokine-stimulated bronchial ep ithelial cells was shown to be inhibited by the synthetic glucocorticoid dexame thasone. ${ }^{120}$ Although cytokine-activated epithelial cells showed increased expression of ICAM-1, this molecule did not seem to be involved in the decreased adhesion of eosinophils observed in the presence of dexamethasone. ${ }^{120}$

\section{Inhibitory proteins}

The anti-inflammatory effects of glucocorticoids may be mediated by increasing the production of inhibitory proteins, such as lipocortins. Lipocortins are members of a superfamily of proteins characterized by their ability to bind calcium and anionic phospholipids, now known as the 'annexins'. ${ }^{121,122}$ In several cell types, but not all, glucocorticoids are inducers of lipocortins, which have an inhibitory effect on the activity of phospholipase $\mathrm{A}_{2} \cdot{ }^{123,124}$ As a result, the synthesis of lipid mediators, including prostaglandins and eicosanoids, will be reduced. However, in human bronchial epithelial cells glucocorticoids do not seem to up-regulate the expression of lipocortins. ${ }^{125}$ Furthermore, no significant difference was found between lipocortin-1 concentration in BAL fluid from asthmatic patients receiving inhaled glucocorticoid therapy and those who were not treated with glucocorticoids. ${ }^{126}$

Recently, glucocorticoids have also been shown to increase the expression of intracellular IL-1 receptor antagonist type I by human bronchial epithelial cells in vitro. ${ }^{127}$ Increased production of this mediator may inhibit the effects of IL-1 agonists, thereby reducing inflammation. However, glucocorticoid treatment of asthmatic patients did not affect the expression of IL-1 receptor antagonist by the bronchial epithelium. $^{78}$

To provide protection against potentially injurious agents, airway epithelial cells secrete a number of mediators, including antiproteases. Secretory leukocyte protease inhibitor (SLPI) is the predominant antiprotease in the airways. Its expression has been show $\mathrm{n}$ to be increased in airway epithelial cells after stimulation with glucocorticoids. ${ }^{128}$

\section{Cellular and Clinical Effects of Glucocorticoids in Asthma}

Several studies have determined the effects of inhaled glucocorticoids on bronchial inflammation, either by measurements in BAL fluid, sputum, or exhaled air, or by performing bronchial biopsies. Although differences can be observed between different trials, these studies have confirmed that glucocorticoid treatment of asthmatic patients reduces the number and activation of inflammatory cells in the airways, together with an improvement of lung function. Nowadays, the potent anti-inflammatory actions of glucocorticoids are thought to underlie the clinical efficacy of oral glucocorticoids. ${ }^{129}$

\section{Effects of glucocorticoids on immunopathology}

Inhaled glucocorticoids decrease the number and activation status of most inflammatory cells in the bronchus, including mast cells, dendritic cells, eosinophils, and T lymphocytes. Changes in cellular infiltration are accompanied by modulated expression of several cytokines. Inhaled glucocorticoids have been show $\mathrm{n}$ to decrease mRNA expression of GM-CSF, IL13, IL -4 , and IL-5, whereas mRNA levels of IL-12 and IFN- $\gamma$ increased, suggesting a shift from a Th2tow ards a more Th1-like environment. ${ }^{77,130,131}$

Glucocorticoid treatment is associated with a reduction in mast cell numbers in the bronchus $^{79,129,132-135}$ and with reduced mast cell associated mediators in BAL fluid. ${ }^{135,136}$ This may be due to a reduction in IL-3 and stem cell factor production, which are necessary for the survival of mast cells in tissue. The (IgE-dependent) release of mediators from mast cells does not seem to be affected by glucocorticoid treatment. ${ }^{137,138}$

Dendritic cells play an important role in presenting antigens to (naive) $\mathrm{T}$ cells. ${ }^{139,140}$ Inhaled glucocorticoids have been shown to reduce the number of dendritic cells in the human bronchial epithelium. $^{141}$

Increased numbers of eosinophils are a prominent feature of asthmatic airways. ${ }^{142-148}$ In vitro studies have shown that many eosinophil functions, including adherence and chemotax is, are diminished following glucocorticoid treatment. ${ }^{138}$ However, most data suggest that eosinophil responses to steroids are likely to be indirect, since eosinophil function is markedly affected by cytokines elaborated from $\mathrm{T}$ lymphocytes (IL-3, IL-4, IL-5, GM-CSF), endothelial cells (GM-CSF) and epithelial cells (GM-CSF). ${ }^{149-153}$ In vivo studies indicate that treatment $w$ ith inhaled steroids reduces the number of eosinophils and eosinophil-related mediators in BAL fluid ${ }^{79,148,154}$ and the number of (activated) eosinophils in bronchial biopsies. ${ }^{79,129,132,133,155}$ Recently, induced sputum has been suggested as a useful tool for evaluating the 
effects of therapy on airway mucosal inflammation. Thus far, most studies have focused on the presence of eosinophils and eosinophil-related mediators. In accordance with the findings in BAL fluid and bronchial biopsies, glucocorticoid treatment was associated with a reduction in sputum eosinophil numbers, eosinophil cationic protein (ECP), and eosinophil peroxidase (EPO). ${ }^{156}$

Glucocorticoids also reduce the number of activated $\mathrm{T}$ lymphocytes in bronchial biopsies and BAL fluid. ${ }^{129,133,134,155,157}$ In addition, inhaled corticosteroids reduced the number of cells expressing mRNA for IL 4 or IL-5, and increased the number of cells expressing mRNA for IFN- $\gamma,{ }^{131,132}$ thereby favouring the development of Th 1 cells. ${ }^{158}$

In addition to the effects of glucocorticoids on epithelial cells described above, inhaled glucocorticoid therapy has been shown to reduce the shedding of epithelial cells. ${ }^{155,159,160}$ No consistent effect of corticosteroids on the thickness of the basement membrane has been observed. ${ }^{79,160,161}$

Besides the suppressive effects on inflammatory cells, inhaled glucocorticoids have also shown to inhibit mucus secretion and microvascular leakage (as determined by the down-regulation of plasma proteins in BAL fluid). ${ }^{160,162-166}$ At present it is not clear whether this is mediated via a direct effect of glucocorticoids on endothelial or mucous cells, or via a reduction of inflammatory mediators that increase mucus secretion and vascular leakage.

\section{Effects of glucocorticoids on lung function}

Treatment with glucocorticoids has been consistently shown not only to reduce the symptoms of asthma, but also bronchial hyperresponsiveness. ${ }^{134,167-169}$ In contrast to the rapid inhibitory effects of $\beta_{2}$-agonists, glucocorticoids given in a single dose are not effective in preventing early allergen-invoked bronchoconstriction, but inhibition of the late response has been clearly demonstrated. ${ }^{170,171}$ In contrast, chronic treatment with either oral or inhaled steroids attenuates even the early bronchoconstriction to allergen, ${ }^{171-173}$ an effect that probably is mediated via the antiinflammatory actions of glucocorticoids already described. Although inhaled glucocorticoids consistently reduce airway hyperreactivity in asthmatics, ${ }^{169}$ even after several months of treatment responsiveness fails to return to the normal range. This may reflect persistence of structural changes that cannot be reversed by steroids (such as the thickening of the basement membrane), despite of suppression of the inflammatory and immunological processes.

\section{Concluding Remarks}

Glucocorticoids are widely used in the treatment of asthma and have anti-inflammatory effects. These effects are mediated either by direct binding of the glucocorticoid/GR complex to GRE in the promoter region of responsive genes, or by an interaction of this complex with transcription factors such as AP-1 and NF-KB. Glucocorticoids inhibit the expression of a large number of inflammation-associated molecules, including cytokines, chemokines, arachidonic acid metabolites, and adhesion molecules. These effects predominantly are mediated via inhibition of NF- $\mathrm{B}$ activity. In contrast, anti-inflammatory mediators, such as NEP and IL-1 receptor antagonist, often are up-regulated by glucocorticoids. The beneficial effects of glucocorticoid therapy in asthma is demonstrated by in vivo studies showing that treatment of asthmatic patients with inhaled glucocorticoids inhibits the inflammation of the airways and simultaneously improves their lung function. These effects may be mediated in part by modulation of epithelial cell functions, since many studies, both in vitro and in vivo, have shown that glucocorticoids are able to modulate the inflammatory functions of bronchial epithelial cells. Further studies on the mechanism of action of glucocorticoids will eventually lead to the development of drugs which specifically inhibit the transcription of inflammatory genes without having negative side effects, and will contribute to a more efficient treatment of asthmatic patients.

\section{References}

1. Carrye r HM, Koelsche GA, Prickman LE, Maytum CK, Lake CF, Williams HL. Effects of cortisone on bronchial asthma and hay fever occuring in subjects sensitive to ragweed pollen. Proc Staff Meet, Mayo Clin 1950; 25: 482-486.

2. Barnes PJ, Pedersen S. Efficacy and safety of inhaled corticosteroids in asthma. Am Rev Respir Dis 1993; 148: S1-S26.

3. Hollenberg SM, Weinberger C, Ong ES, et al. Primary structure and expression of a functional human glucocorticoid receptor cDNA. Nature 1985; 318: 635-641

4. Hollenberg SM, Giguere V, Segui P, Evans RM. Colocalization of DNAbinding and transcriptional activation functions in the human glucocorticoid receptor. Cell 1987; 49: 39-46.

5. Kumar V, Green S, Staub A, Chambon P. Localisation of the oestradiol binding and putative DNA-binding domains of the human oestrogen receptor. EMBOJ 1986; 5: 2231-2236.

6. Rusconi S, Yamamoto KR. Functional dissection of the hormone and DNA binding activities of the glucocorticoid receptor. EMBOJ 1987; 6: 1309-1315.

7. Evans RM. The steroid and thyroid hormone receptor superfamily. Science 1988; 240: 889-895.

8. Evans RM, Hollenberg SM. Cooperative and positional independent trans-activation domains of the human glucocorticoid receptor. Cold Spring Harb Symp Quant Biol 1988; 53: 813-818.

9. Picard D, Yamamoto KR. Two signals mediate hormone-dependent nuclear localization of the glucocorticoid receptor. $E M B O J 1987$; 6: $3333-3340$

10. Kumar V, Chambon P. The estrogen receptor binds tightly to its responsive element as a ligand-induced homodimer. Cell 1988; 55: $145-156$.

11. Freedman LP, Luisi BF, Korszun ZR, Basavappa R, Sigler PB, Yamamoto $K R$. The function and structure of the metal coordination sites within the glucocorticoid receptor DNA binding domain. Nature 1988; 334: $543-546$.

12. Freedman LP. Anatomy of the steroid receptor zinc finger region. Endocr Rev 1992; 13: 129-145.

13. Luisi BF, Xu WX, Otw inow ski Z, Freedman LP, Yamamoto KR, Sigle r PB. Crystallographic analysis of the interaction of the glucocorticoid receptor with DNA. Nature 1991; 352: 497-505.

14. Schena M, Freedman LP, Yamamoto KR. Mutations in the glucocorticoid receptor zinc finger region that distinguish interdigitated DNA binding and transcriptional enhancement activities. Genes Dev 1989; 3: $1590-1601$ 
15. de Waal RM. The anti-inflammatory activity of glucocorticoids. Mol Biol Rep 1994; 19: 81-88

16. Encio IJ, Detera-Wadleigh SD. The genomic structure of the human glucocorticoid receptor. J Biol Chem 1991; 266: 7182-7188.

17. Otto C, Reichardt HM, Schutz G. Absence of glucocorticoid receptorbeta in mice. J Biol Chem 1997; 272: 26665-26668.

18. Hecht K, Carlstedt-Duke J, Stierna P, Gustafsson J, Bronnegard M, Wikstrom AC. Evidence that the beta-isoform of the human glucocorticoid receptor does not act as a physiologically significant repressor. J Biol Chem 1997; 272: 26659-26664.

19. Oakley RH, Webster JC, Sar M, Parker CR, Jr, Cidlowski JA. Ex pression and subcellular distribution of the beta-isoform of the human glucocorticoid receptor. Endocrinology 1997; 138: 5028-5038.

20. Burnste in KL, Cidlowski JA. The down side of glucocorticoid receptor regulation. Mol Cell Endocrinol 1992; 83: C1-C8.

21. Bronnegard M. Steroid receptor number. Individual variation and downregulation by treatment. Am J Respir Crit Care Med 1996; 154: S28-S32.

22. Rosewicz S, McDonald AR, Maddux BA, Goldfine ID, Miesfeld RL, Logsdon CD. Mechanism of glucocorticoid receptor down-regulation by glucocorticoids. J Biol Chem 1988; 263: 2581-2584.

23. Korn SH, Wouters EF, Wesseling G, Arends JW, Thunnissen FB. In vitro and in vivo modulation of alpha- and beta-glucocorticoid-receptor mRNA in human bronchial epithelium. Am J Respir Crit Care Med 1997; 155: 1117-1122.

24. Kam JC, Szefler SJ, Surs W, Sher ER, Leung DY. Combination IL-2 and IL-4 reduces glucocorticoid receptor-binding affinity and $\mathrm{T}$ cell response to glucocorticoids. J Im munol 1993; 151: 3460-3466.

25. Rakasz E, Gal A, Biro J, Balas G, Falus A. Modulation of glucocorticosteroid binding in human lymphoid, monocytoid and hepatoma cell lines by inflammatory cytokines interleukin (IL)-1 beta, IL-6 and tumour necrosis factor (TNF)-alpha. Scand J Immunol 1993; 37 684-689.

26. Salkowski CA, Vogel SN. Lipopolysaccharide increases glucocorticoid receptor expression in murine macrophages. A possible mechanism for glucocorticoid-mediated suppression of endotoxicity. J Im munol 1992; 149: 4041-4047.

27. Salkow ski CA, Vogel SN. IFN-gamma mediates increased glucocorticoid receptor expression in murine macrophages. J Im munol 1992; 148 $2770-2777$.

28. Verheggen MM, van Hal PT, Adriaansen-Soeting PW, et al. Modulation of glucocorticoid receptor expression in human bronchial epithelial cell lines by IL-1 beta, TNF-alpha and LPS. Eur Respir J 1996; 9 2036-2043

29. Adcock IM, Gilbey T, Gelder CM, Chung KF, Barnes PJ. Glucocorticoid receptor localization in normal and asthmatic lung. Am J Respir Crit Care Med 1996; 154: 771-782.

30. Gustafsson JA, Carlstedt-Duke J, Poellinger L, et al. Biochemistry, molecular biology, and physiology of the glucocorticoid receptor. Endocr Rev 1987; 8: 185-234.

31. Mendel DB, Orti E. Isoform composition and stoichiometry of the approximately $90 \mathrm{kDa}$ heat shock protein associated with glucocorticoid receptors. J Biol Chem 1988; 263: 6695-6702.

32. Smith DF, Stensgard BA, Welch WJ, Toft DO. Assembly of progesterone receptor with heat shock proteins and receptor activation are ATP mediated events. J Biol Chem 1992; 267: 1350-1356.

33. Sanchez ER. Hsp56: a novel heat shock protein associated with untransformed steroid receptor complexes. J Biol Chem 1990; 265 22067-22070.

34. Lebeau MC, Massol N, Herrick J, et al. P59, an hsp 90-binding protein. Cloning and sequencing of its cDNA and prepration of a peptidedirected polyclonal antibody. J Biol Chem 1992; 267: 4281-4284

35. Truss M, Beato M. Steroid hormone receptors: interaction with deoxyribonucle ic acid and transcription factors. Endocr Rev 1993; 14 459-479.

36. Beato M. Gene regulation by steroid hormones. Cell 1989; 56 335-344.

37. Schule R, Rangarajan P, Kliewer S, et al. Functional antagonism be tween oncoprotein c-Jun and the glucocorticoid receptor. Cell 1990; 62 1217-1226.

38. Strahle U, Schmid W, Schutz G. Synergistic action of the glucocorticoid receptor with transcription factors. EMBO J 1988; 7: 3389-3395.

39. Didonato JA, Saatcioglu F, Karin M. Molecular mechanisms of immunosuppression and anti-inflammatory activities by glucocorticoids. $\mathrm{Am} \mathrm{J}$ Respir Crit Care Med 1996; 154: S11-S15.

40. Parker M. Enhancer elements activated by steroid hormones? Nature 1983; 304: 687-688.

41. Becker P, Renkawitz R, Schutz G. Tissue-specific DNaseI hypersensitive sites in the $5^{\prime}$-flanking sequences of the tryptophan oxygenase and the tyrosine aminotransferase genes. EMBO J 1984; 3: 2015-2020.

42. Fritton HP, Igo-Kemenes T, Nowock J, Strech-Jurk U, Theisen M, Sippel AE. Alternative sets of DNase Ihypersensitive sites characterize the various functional states of the chicken lysozyme gene. Nature 1984 311: 163-165.

43. Zaret KS, Yamamoto KR. Reversible and persistent changes in chromatin structure accompany activation of a glucocorticoid-dependent enhancer element. Cell 1984; 38: 29-38.
44. Perlmann T, Wrange O. Specific glucocorticoid receptor binding to DNA reconstituted in a nucleosome. EMBO J 1988; 7: 3073-3079.

45. Barnes PJ. Molecular mechanisms of steroid action in asthma. $J$ Allergy Clin Im munol 1996; 97: 159-168.

46. Ransone LJ, Verma IM. Nuclear proto-oncogenes fos and jun. Annu Rev Cell Biol 1990; 6: 539-557.

47. Angel P, Karin M. The role of Jun, Fos and the AP-1 complex in cellproliferation and transformation. Biochim Biophys Acta 1991; 1072: 129-157.

48. Jonat C, Rahmsdorf HJ, Park KK, et al. Antitumor promotion and antiinflammation: down-modulation of AP-1 (Fos/Jun) activity by glucocorticoid hormone. Cell 1990; 62: 1189-1204.

49. Yang-Yen HF, Chambard JC, Sun YL, et al. Transcriptional interference between c-Jun and the glucocorticoid receptor: mutual inhibition of DNA binding due to direct protein-protein interaction. Cell 1990; 62: 1205-1215.

50. Lenardo MJ, Baltimore D. NFkappa B: a pleiotropic mediator of inducible and tissue-specific gene control. [Review]. Cell 1989; 58: 227-229.

51. Ray A, Prefontaine KE. Physical association and functional antagonism between the p65 subunit of transcription factor NFkappa B and the glucocorticoid receptor. Proc Natl Acad Sci USA 1994; 91: $752-756$.

52. Grilli M, Chiu JJ, Lenardo MJ. NF-kappa B and Rel: participants in a multiform transcriptional regulatory system. Int Rev Cytol 1993; 143 $1-62$.

53. Siebenlist U, Franzoso G, Brown K. Structure, regulation and function of NF-kappa B. Annu Rev Cell Biol 1994; 10: 405-455.

54. Auphan N, DiDonato JA, Rosette C, Helmberg A, Karin M. Immunosuppression by glucocorticoids: inhibition of NF-kappa B activity through induction of I kappa B synthesis. Science 1995; 270: 286-290.

55. Scheinman RI, Cogswell PC, Lofquist AK, Baldwin AS Jr. Role of transcriptional activation of I kappa B alpha in mediation of immunosuppression by glucocorticoids. Science 1995; 270: 283-286.

56. Haskill S, Beg AA, Tompkins SM, et al. Characterization of an immediateearly gene induced in adherent monocytes that encodes I kappa B-like activity. Cell 1991; 65: 1281-1289.

57. Finco TS, Baldw in AS. Mechanistic aspects of NF-kappa B regulation: the emerging role of phosphorylation and proteolysis. Im m unity 1995; 3: 263-372.

58. Mukaida N, Morita M, Ishikawa $\mathrm{Y}$, et al. Novel mechanism of glucocorticoid-mediated gene repression. Nuclear factor-kappa B is target for glucocorticoid-mediated interleukin 8 gene repression. J Bio Chem 1994; 269: 13289-13295.

59. Caldenhoven E, Liden J, Wissink S, et al. Negative cross-talk between RelA and the glucocorticoid receptor: a possible mechanism for the antiinflammatory action of glucocorticoids. Mol Endocrinol 1995; 9: 401-412.

60. Yamamoto KK, Gonzalez GA, Menzel P, Rivier J, Montminy MR. Characterization of a bipartite activator domain in transcription factor CREB. Cell 1990; 60: 611-617.

61. Adcock IM, Stevens DA, Barnes PJ. Interactions of glucocorticoids and beta 2-agonists. Eur Respir J 1996; 9: 160-168.

62. Adcock IM, Peters MJ, Brown CR, Stevens DA, Barnes PJ. High concentrations of beta-adrenergic agonists inhibit DNA binding of glucocorticoids in human lung in vitro. Biochem Soc Trans 1995; 23: 217 .

63. Peters MJ, Adcock IM, Brown CR, Barnes PJ. Beta-adrenoceptor agonists interfere with glucocorticoid receptor DNA binding in rat lung. Eur J Pharmacol 1995; 289: 275-281.

64. Peppel K, Vinci JM, Baglioni C. The AU-rich sequences in the 3 untranslated region mediate the increased turnover of interferon mRNA induced by glucocorticoids. J Exp Med 1991; 173: 349-355.

65. Lee SW, Tsou AP, Chan H, et al. Glucocorticoids selectively inhibit the transcription of the interleukin 1 beta gene and decrease the stability of interleukin 1 beta mRNA. Proc Natl Acad Sci USA 1988; 85: 1204-1208.

66. Schwiebert LM, Stellato C, Schleimer RP. The epithelium as a target of glucocorticoid action in the treatment of asthma. Am J Respir Crit Care Med 1996; 154: S16-S19.

67. LeVan TD, Behr FD, Adkins KK, Miesfeld RL, Bloom JW. Glucocorticoid receptor signaling in a bronchial epithelial cell line. Am J Physiol 1997; 272: L838-L843.

68. Cox G, OhtoshiT, Vancheri C, et al. Promotion of eosinophil survival by human bronchial epithelial cells and its modulation by steroids. $\mathrm{Am}$ Respir Cell Mol Biol 1991; 4: 525-531.

69. Marini M, Vittori E, Hollemborg J, Mattoli S. Expression of the potent inflammatory cytokines, granulocyte-macrophage-colony-stimulating factor and interleukin-6 and interleukin-8, in bronchial epithelial cells of patients with asthma. I Allergy Clin Immunol 1992; 89: 1001-1009.

70. Berkman N, Robichaud A, Krishnan VL, et al. Expression of RANTES in human airway epithelial cells: effect of corticosteroids and interleukin4, -10 and -13. Im m unology 1996; 87: 599-603.

71. Stellato C, Beck LA, Gorgone GA, et al. Expression of the chemokine RANTES by a human bronchial epithelial cell line. Modulation by cytokines and glucocorticoids. J Imm unol 1995; 155: 410-418. 
72. Kw on OJ, Au BT, Collins PD, et al. Inhibition of in terle ukin-8 expression by dexame thasone in human cultured airway epithelial cells. Im $m$ unology 1994; 81: 389-394.

73. Lilly CM, Nakamura H, Kesselman H, et al. Expression of eotaxin by human lung epithelial cells: induction by cytokines and inhibition by glucocorticoids. J Clin Invest 1997; 99: 1767-1773.

74. Bedard M, McClure CD, Schiller NL, Francoeur C, Cantin A, Denis M. Rele ase of interleukin- 8 , interleukin- 6 , and colony-stimulating factors by upper airway epithelial cells: implications for cystic fibrosis. $A m J$ Respir Cell Mol Biol 1993; 9: 455-462.

75. Kwon OJ, Jose PJ, Robbins RA, Schall TJ, Williams TJ, Barnes PJ. Glucocorticoid inhibition of RANTES expression in human lung epithelial cells. Am J Respir Cell Mol Biol 1995; 12: 488-496.

76. Levine SJ, Larivee P, Logun C, Angus CW, Shelhamer JH. Corticosteroids differentially regulate secretion of IL-6, IL-8, and G-CSF by a human bronchial epithelial cell line. Am J Physiol 1993; 265 L360-L368.

77. Sousa AR, Poston RN, Lane SJ, Nakhosteen JA, Lee TH. Detection of GMCSF in asthmatic bronchial epithelium and decrease by inhaled corticosteroids. Am Rev Respir Dis 1993; 147: 1557-1561.

78. Sousa AR, Trigg CJ, Lane SJ, et a l. Effect of inhaled glucocorticoids on IL 1 beta and IL-1 receptor antagonist (IL-1 ra) expression in asthmatic bronchial epithelium. Thorax 1997; 52: 407-410.

79. Trigg CJ, Manolitsas ND, Wang J, et al. Placebo-controlled immunopathologic study of four months of inhaled corticosteroids in asthma. Am J Respir Crit Care Med 1994; 150: 17-22.

80. Wang JH, Devalia JL, Xia C, Sapsford RJ, Davies RJ. Expression of RANTES by human bronchial epithelial cells in vitro and in vivo and the effect of corticosteroids. Am J Respir Cell Mol Biol 1996; 14 27-35.

81. Bai TR, Zhou D, Weir T, et al. Substance P (NK1)- and neurokinin A (NK2)-receptor gene expression in inflammatory airway diseases. $A m \mathrm{~J}$ Physiol 1995; 269: L309-L317.

82. Adcock IM, Peters M, Gelder C, Shirasaki H, Brown CR, Barnes PJ Increased tachykinin receptor gene expression in asthmatic lung and its modulation by steroids. J Mol Endocrinol 1993; 11: 1-7.

83. Mak JC, Nishikawa M, Shirasaki H, Miyayasu K, Barnes PJ. Protective effects of a glucocorticoid on downregulation of pulmonary beta 2-adrenergic receptors in vivo. J Clin Invest 1995; 96: 99-106.

84. Tan S, Hall IP, Dewar J, Dow E, Lipworth B. Association between beta 2-adrenoceptor polymorphism and susceptibility to bronchodilator desensitisation in moderately severe stable asthmatics. Lancet 1997; 350: 995-999.

85. Colotta F, Re F, Muzio M, et al. Interleukin-1 type II receptor: a decoy target for IL-1 that is regulated by IL-4. Science 1993; 261: 472-475.

86. Dower SK, Fanslow W, Jacobs C, Waugh S, Sims JE, Widmer MB. Interleukin-I antagonists. Ther Im munol 1994; 1: 113-122.

87. Re F, Muzio M, De Rossi M, et al. The type II 'receptor' as a decoy target for interleukin 1 in polymorphonuclear leukocytes: characterization of induction by dexamethasone and ligand binding properties of the released decoy receptor. J Exp Med 1994; 179: 739-743.

88. Levine SJ, Logun C, Chopra DP, Rhim JS, Shelhamer JH. Protein kinase $\mathrm{C}$, interleukin-1 beta, and corticosteroids regulate shedding of the type I, $55 \mathrm{kDa}$ TNF receptor from human airw ay epithelial cells. Am J Respir Cell Mol Biol 1996; 14: 254-261.

89. Geisterfer M, Richards C, Baumann M, Fey G, Gywnne D, Gauldie J. Regulation of IL- 6 and the hepatic IL- 6 receptor in acute inflammation in vivo. Cyto kine 1993; 5: 1-7.

90. Snyers L, De Wit L, Content J. Glucocorticoid up-regulation of highaffinity interleukin 6 receptors on human epithelial cells. Proc Natl Acad Sci USA 1990; 87: 2838-2842.

91. Takizaw a H, Ohtoshi T, Yamashita N, Oka T, Ito K. Interleukin 6-receptor expression on human bronchial epithelial cells: regulation by IL-1 and IL-6. Am J Physiol 1996; 270: L346-L352.

92. Guo FH, De Raeve HR, Rice TW, Stuehr DJ, Thunnissen FB, Erzurum SC. Continuous nitric oxide synthesis by inducible nitric oxide synthase in normal human airw ay epithelium in vivo. Proc Natl Acad Sci USA 1995 92: 7809-7813.

93. Robbins RA, Barnes PJ, Springall DR, et al. Expression of inducible nitric oxide in human lung epithelial cells. Biochem Biophys Res Commun 1994; 203: 209-218.

94. Berkman N, Robichaud A, Robbins RA, et al. Inhibition of inducible nitric ox ide synthase expression by interleukin 4 and interleukin-13 in human lung epithelial cells. Im munology 1996; 89: 363-367.

95. Adcock IM, Brow n CR, Kw on O, Barnes PJ. Oxidative stress induces NF kappa B DNA binding and inducible NOS mRNA in human epithelial cells. Biochem Biophys Res Commun 1994; 199: 1518-1524.

96. Xie QW, Kashiwabara Y, Nathan C. Role of transcription factor NF-kappa $\mathrm{B} / \mathrm{Rel}$ in induction of nitric oxide synthase. J Biol Chem 1994; 269: 4705-4708.

97. Barnes PJ. Nitric oxide and asthma. Res Immunol 1995; 146: $698-702$.

98. Schalkwijk C, Vervoordeldonk M, Pfeilschifter J, Marki F, van den Bosch H. Cytokine- and forskolin-induced synthesis of group II phospholipase A2 and prostaglandin E2 in rat mesangial cells is prevented by dexamethasone. Biochem Biophys Res Commun 1991; 180: 46-52.
99. Mitchell JA, Belvisi MG, Akarasereenont P, et al. Induction of cyclooxygenase-2 by cytokines in human pulmonary epithelial cells: regulation by dexamethasone. $\mathrm{Br} J$ Pharmacol 1994; 113: $1008-1014$.

100. van der Velden VHJ, Naber BAE, Van der Spoel P, Hoogsteden HC, Versnel MA. Cytokines and glucocorticoids modulate human bronchial epithelial cell peptidases. Cytokine 1998; 10: 55-65.

101. Lang Z, Murlas CG. Dexamethasone increases airway epithelial cell neutral endopeptidase by enhancing transcription and new protein synthesis. Lung 1993; 171: 161-172.

102. Borson DB, Gruenert DC. Glucocorticoids induce neutral endopeptidase in transformed human tracheal epithelial cells. Am J Physiol 1991; 260: L83-L89.

103. Nadel JA, Borson DB. Modulation of neurogenic inflammation by neutral endopeptidase. Am Rev Respir Dis 1991; 143: S33-S36.

104. Sont JK, van Krieken JH, van Klink HC, et al. Enhanced expression of neutral endopeptidase (NEP) in airway epithelium in biopsies from steroid-versus nonsteroid-treated patients with atopic asthma. Am Respir Cell Mol Biol 1997; 16: 549-556.

105. Gandhi CR, Be rkowitz DE, Watkins WD. Endothelins. Biochemistry and pathophysiologic actions. Anesthesio logy 1994; 80: 892-905.

106. Vittori E, Marini M, Fasoli A, De Franchis R, Mattoli S. Increased expression of endothelin in bronchial epithelial cells of asthmatic patients and effect of corticosteroids. Am Rev Respir Dis 1992; 146 $1320-1325$

107. Hay DW, Hubbard WC, Undem BJ. Endothelin-induced contraction and mediator release in human bronchus. Br J Pharmacol 1993; 110 392-398.

108. Mattoli S, Mezzetti M, Riva G, Allegra L, Fasoli A. Specific binding of endothelin on human bronchial smooth muscle cells in culture and secretion of endothelin-like material from bronchial epithelial cells. $\mathrm{Am}$ J Respir Cell Mol Biol 1990; 3: 145-151.

109. Barnes PJ. Endothelins and pulmonary diseases. J Appl Physiol 1994; 77: 1051-1059.

110. Mansoor AM, Honda M, Saida K, et al. Endothelin induced collagen remodeling in experimental pulmonary hypertension. Biochem Biophys Res Commun 1995; 215: 981-986.

111. Rizvi MA, Katw a L, Spadone DP, Myers PR. The effects of endothelin-1 on collagen type I and type III synthesis in cultured porcine coronary artery vascular smooth muscle cells. J Mol Cell Biol 1996; 28: 243-252.

112. Dawes KE, Cambrey AD, Campa JS, et al. Changes in collagen metabolism in response to endothelin-1: evidence for fibroblast heterogeneity. Int J Biochem Cell Biol 1996; 28: 229-238.

113. Springall DR, Howarth PH, Counihan H, Djukanovic R, Holgate ST, Polak JM. Endothelin immunoreactivity of airway epithelium in asthmatic patients. Lancet 1991; 337: 697-701.

114. Redington AE, Springall DR, Meng QH, et al. Immunore active endothelin in bronchial biopsy specimens: increased expression in asthma and modulation by corticosteroid therapy. J Allergy Clin Im munol 1997; 100: $544-552$.

115. Redington AE, Springall DR, Meng QH, et al. Immunoreactive endothelin in bronchial biopsy specimens: increased expression in asthma and modulation by corticosteroid therapy. J Allergy Clin Im munol 1997; 100: $544-552$

116. Cronstein BN, Kimmel SC, Levin RI, Martiniuk F, Weissmann G. A mechanism for the antiinflammatory effects of corticosteroids: the glucocorticoid receptor regulates leukocyte adhesion to endothelial cells and expression of endothelial-leukocyte adhesion molecule 1 and intercellular adhesion molecule 1. Proc Natl Acad Sci USA 1992; 89 9991-9995.

117. van de Stolpe A, Caldenhoven E, Raaijmakers JA, van der Saag PT, Koenderman L. Glucocorticoid-mediated repression of intercellular adhesion molecule-1 expression in human monocytic and bronchial epithelial cell lines. Am J Respir Cell Mol Biol 1993; 8: 340-347.

118. Paolieri F, Battifora M, Riccio AM, et al. Inhibition of adhesion molecules by budesonide on a human epithelial cell line (lung carcinoma). Allergy 1997; 52: $935-943$.

119. Montefort S, Herbert CA, Robinson C, Holgate ST. The bronchial epithelium as a target for inflammatory attack in asthma. [Review]. Clin Exp Allergy 1992; 22: 511-520.

120. Sato M, Takizawa H, Kohyama T, et al. Eosinophil adhesion to human bronchial epithelial cells: regulation by cytokines. Int Arch Allergy Immunol 1997; 113: 203-205.

121. Goulding NJ, Guyre PM. Regulation of inflammation by lipocortin 1 . Im munol Today 1992; 13: 295-297.

122. Geisow MI, Walker JH, Boustead C, Taylor W. Annexins-new family of Ca2+-regulated-phospholipid binding protein. Biosci Rep 1987; 7: $289-298$.

123. Flower RJ. Eleventh Gaddum memorial lecture. Lipocortin and the mechanism of action of the glucocorticoids. Br J Pharm a col 1988; 94 987-1015.

124. Wallner BP, Mattaliano RJ, Hession C, et al. Cloning and expression of human lipocortin, a phospholipase A2 inhibitor with potential antiinflammatory activity. Nature 1986; 320: 77-81.

125. Verheggen MM, De Bont HI, Adriaansen-Soeting PWC, et al. Expression of lipocortins in human bronchial epithelial cells: effects of IL-1B, TNFa, LPS and dexame thasone. Med Inflam 1996; 5: 210-217. 
126. van Hal PT, Overbeek SE, Hoogsteden HC, et al. Eicosanoids and lipocortin-1 in BAL fluid in asthma: effects of smoking and inhaled glucocorticoids. J Appl Physiol 1996; 81: 548-555.

127. Levine SJ, Benfield T, Shelhamer JH. Corticosteroids induce intracellular interleukin-1 receptor antagonist type I expression by a human airway epithelial cell line. Am J Respir Cell Mol Biol 1996; 15: 245-251.

128. Abbinante-Nissen JM, Simpson LG, Leikauf GD. Corticosteroids increase secretory leukocyte protease inhibitor transcript levels in airway epithelial cells. Am J Physiol 1995; 268: L601-L606.

129. Djukanovic R, Homeyard S, Gratziou C, et al. The effect of treatment with oral corticosteroids on asthma symptoms and airway inflammation. Am J Respir Crit Care Med 1997; 155: 826-832.

130. Naseer T, Minshall EM, Leung DY, et al. Expression of IL-12 and IL-13 mRNA in asthma and their modulation in response to steroid therapy. Am J Respir Crit Care Med 1997; 155: 845-851.

131. Robinson D, Hamid Q, Bentley A, Ying S, Kay AB, Durham SR. Activation of CD4+ T cells, increased TH2-type cytokine mRNA expression, and eosinophil recruitment in bronchoalveolar lavage after allergen inhalation challenge in patients with atopic asthma. JAllergy Clin Im munol 1993; 92: 313-324.

132. Bentley AM, Hamid Q, Robinson DS, et al. Prednisolone treatment in asthma. Reduction in the numbers of eosinophils, T cells, tryptase-only positive mast cells, and modulation of IL 4 , IL-5, and interferon-gamma cytokine gene expression within the bronchial mucosa. Am J Respir Crit Care Med 1996; 153: 551-556.

133. Djukanovic R, Wilson JW, Britten KM, et al. Effect of an inhaled corticosteroid on airway inflammation and symptoms in asthma. $\mathrm{Am}$ Rev Respir Dis 1992; 145: 669-674.

134. Booth H, Richmond I, Ward C, Gardiner PV, Harkaw at R, Walters EH. Effect of high dose inhaled fluticasone propionate on airway inflammation in asthma. Am J Respir Crit Care Med 1995; 152: 45-52.

135. Olivieri D, Chetta A, Del Donno M, et al. Effect of short-term treatment with low-dose inhaled fluticasone propionate on airway inflammation and remodeling in mild asth ma: a placebo-controlled study. Am J Respir Crit Care Med 1997; 155: 1864-1871.

136. Duddridge M, Ward C, Hendrick DJ, Walters EH. Changes in bronchoalveolar lavage inflammatory cells in asthmatic patients treated w ith high dose inhaled beclomethasone dipropionate. Eur Respir J 1993; 6 489-497.

137. Schleimer RP, Schulman ES, MacGlashan DW Jr, et al. Effects of dexamethasone on mediator release from human lung fragments and purified human lung mast cells. J Clin Invest 1983; 71: 1830-1835.

138. Schleimer RP. Effects of glucocorticosteroids on inflammatory cells relevant to the ir therapeutic applications in asthma. Am Rev Respir Dis 1990; 141: S59-S69.

139. Davis MM, Bjorkman PJ. T-cell antigen receptor genes and T-cell recognition. Nature 1988; 334: 395-402.

140. Inaba K, Steinman RM. Resting and sensitized $T$ lymphocytes exhibit distinct stimulatory (antigen-presenting cell) require ments for grow th and lymphokine release. J Exp Med 1984; 160: 1717-1735.

141. Möller GM, Overbeek SE, van Helden-Meeuwsen CG, et al. Increased number of dendritic cells in the bronchial mucosa of atopic asthmatics: dow nregulation by inhaled corticosteroids. Clin Exp Allergy 1996; 26: $517-524$

142. Bousquet J, Chanez P, Lacoste JY, et al. eosinophilic inflammation in asthma. N Engl J Med 1990; 323: 1033-1039.

143. Wardlaw AJ, Kay AB. The role of the eosinophil in the pathogenesis of asthma. Alle rgy 1987; 42: 321-335.

144. Djukanovic R, Wilson JW, Britten KM, et al. Quantitation of mast cells and eosinophils in the bronchial mucosa of symptomatic atopic asthmatics and healthy control subjects using immunohistochemistry. Am Rev Respir Dis 1990; 142: 863-871.

145. Djukanovic R, Roche WR, Wilson JW, et al. Mucosal inflammation in asthma. Am Rev Respir Dis 1990; 142: 434-457.

146. Azzawi M, Bradley B, Jeffery PK, et al. Identification of activated T lymphocytes and eosinophils in bronchial biopsies in stable atopic asthma. Am Rev Respir Dis 1990; 142: 1407-1413.

147. Beasley R, Roche WR, Roberts JA, Holgate ST. Cellular events in the bronchi in mild asthma and after bronchial provocation. Am Rev Respir Dis 1989; 139: 806-817.

148. Adelroth E, Rosenhall L, Johansson SA, Linden M, Venge P. Inflammatory cells and eosinophilic activity in asthmatics investigated by bronchoal veolar lavage. The effects of antiasthmatic treatment with budesonide or te rbutaline. Am Rev Respir Dis 1990; 142: 91-99.

149. Lopez AF, Williamson DJ, Gamble JR, et al. Recombinant human granulocyte-macrophage colony-stimulating factor stimulates in vitro mature human neutrophil and eosinophil function, surface receptor expression, and survival. J Clin Invest 1986; 78: 1220-1228.

150. Owen WF, Rothenberg ME, Petersen J, et al. Interleukin 5 and phenotypically altered eosinophils in the blood of patients with the idiopathic hypereosinophilic syndrome. J Exp Med 1989; 170: $343-348$.

151. Rothenberg ME, Owen WF Jr, Silberste in DS, et al. Human eosinophils have prolonged survival, enhanced functional properties, and become hypodense when exposed to human interleukin 3. J Clin Invest 1988 81: 1986-1992.
152. Clutterbuck EJ, Hirst EM, Sanderson CJ. Human interleukin-5 (IL-5) regulates the production of eosinophils in human bone marrow cultures: comparison and interaction with IL-1, IL-3, IL-6, and GMCSF Blood 1989; 73: 1504-1512.

153. Nakamura Y, Azuma M, Okano Y, et al. Upregulatory effects of interleukin 4 and interleukin-13 but not interleukin-10 on granulocyte/ macrophage colony-stimulating factor production by human bronchial epithelial cells. Am J Respir Cell Mol Biol 1996; 15: 680-687.

154. Robinson DS, Assoufi B, Durham SR, Kay AB. Eosinophil cationic prote in (ECP) and eosinophil protein X (EPX) concentrations in serum and bronchial lavage fluid in asthma. Effect of prednisolone treatment. Clin Exp Allergy 1995; 25: 1118-1127.

155. Laitinen LA, Laitinen A, Haahtela T. A comparative study of the effects of an inhaled corticosteroid, budesonide, and a beta 2-agonist, terbutaline, on airway inflammation in newly diagnosed asthma: a randomized, double-blind, parallel-group controlled trial. J Allergy Clin Im munol 1992; 90: $32-42$.

156. Keatings VM, Jatakanon A, Worsdell YM, Barnes PJ. Effects of inhaled and oral glucocorticoids on inflammatory indices in asthma and COPD. $\mathrm{Am}$ J Respir Crit Care Med 1997; 155: 542-548.

157. Burke C, Power CK, Norris A, Condez A, Schmekel B, Poulter LW. Lung function and immunopathological changes after inhaled corticosteroid therapy in asthma. Eur Respir J 1992; 5: 73-79.

158. Krouwels FH, van der Heijden JF, Lutter R, van Neerven RJ, Jansen HM, Out TA. Glucocorticosteroids affect functions of airway- and bloodderived human Tcell clones, favoring the Th1 profile through two mechanisms. Am J Respir Cell Mol Biol 1996; 14: 388-397.

159. Lundgren R. Scanning electron microscopic studies of bronchial mucosa before and during treatment with beclomethasone dipropionate inhalations. Scand J Respir Dis Suppl 1977; 101: 179-187.

160. Lundgren JD, Hirata F, Marom Z, et al. Dexamethasone inhibits respiratory glycoconjugate secretion from feline airways in vitro by the induction of lipocortin (lipomodulin) synthesis. Am Rev Respir Dis 1988; 137: 353-357

161. Jeffery PK, Godfrey RW, Adelroth E, Nelson F, Rogers A, Johansson SA. Effects of treatment on airway inflammation and thickening of basement membrane reticular collagen in asthma. A quantitative light and electron microscopic study. Am Rev Respir Dis 1992; 145: 890-899.

162. Schleimer RP. An overview of glucocortic oid anti-inflammatory actions. Eur J Clin Pharmacol 1993; 45: S3-S7.

163. van de Graaf EA, Out TA, Roos CM, Jansen HM. Respiratory membrane permeability and bronchial hyperreactivity in patients with stable asthma. Effects of therapy with inhaled steroids. Am Rev Respir Dis 1991; 143: 362-368.

164. Erjefalt I, Persson CG. Anti-asthma drugs attenuate inflammatory leakage of plasma into airway lumen. Acta Physiol Scand 1986; 128: 653-654.

165. Boschetto P, Rogers DF, Fabbri LM, Barnes PJ. Corticosteroid inhibition of airway microvascular leakage. Am Rev Respir Dis 1991; 143: 605-609.

166. Shimura S, Sasaki T, Ikeda K, Yamauchi K, Sasaki H, Takishima T. Direct inhibitory action of glucocorticoid on glycoconjugate secretion from airway submucosal glands. Am Rev Respir Dis 1990; 141 $1044-1049$.

167. Osterman K, Carlholm M, Ekelund J, et al. Effect of 1 year daily treatment with 400 microg budesonide (Pulmicort Turbuhaler) in newly diagnosed asthmatics. Eur Respir J 1997; 10: 2210-2215.

168. Simons FE. A comparison of beclomethasone, salmeterol, and placebo in children with asthma. Canadian Beclomethasone DipropionateSalmeterol Xinafoate Study Group. N Engl J Med 1997; 337: $1659-1665$.

169. Barnes PJ. Effect of corticoste roids on airw ay hyperresponsiveness. $A m$ Rev Respir Dis 1990; 141: S70-S76.

170. Cockcroft DW, Murdock KY. comparative effects of inhaled salbutamol, sodium cromoglycate, and beclomethasone dipropionate on allergeninduced early asthmatic responses, late asthmatic responses, and increased bronchial responsiveness to histamine. J Allergy Clin Im munol 1987; 79: 734-740.

171. Dahl R, Johansson SA. Importance of duration of treatment with inhaled budesonide on the immediate and late bronchial reaction. Eur J Respir Dis Suppl 1982; 122: 167-175.

172. Burge PS. The effects of corticosteroids on the immediate asthmatic reaction. Eur J Respir Dis Suppl 1982; 122: 163-166.

173. Martin GL, Atkins PC, Dunsky EH, Zweiman B. Effects of theophylline, terbutaline, and prednisone on antigen-induced bronchospasm and mediator release. J Allergy Clin Immunol 1980; 66: 204-212.

ACKNOWLEDGEMENTS. I acknowledge Mr T. M. van Os for preparing the figure.

\section{Received 28 April 1998; accepted 7 May 1998}




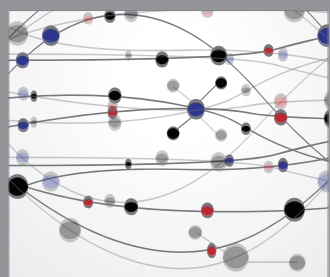

The Scientific World Journal
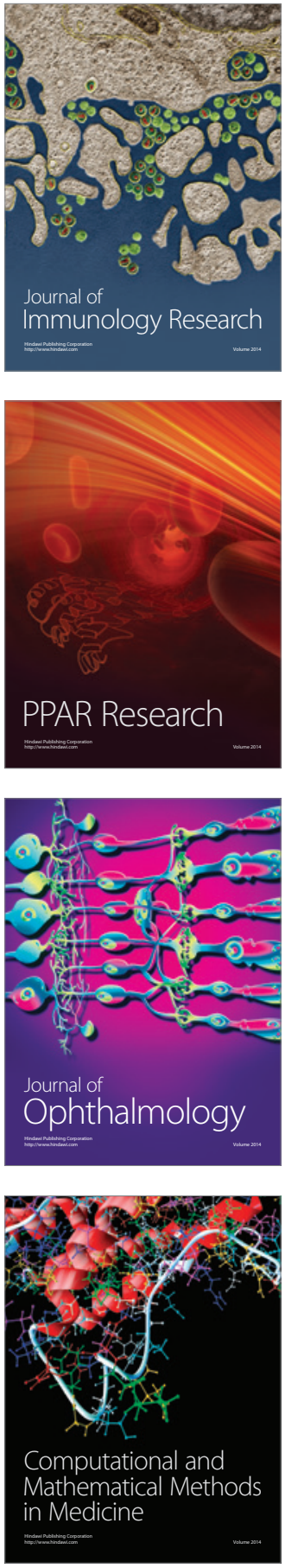



Gastroenterology

Research and Practice
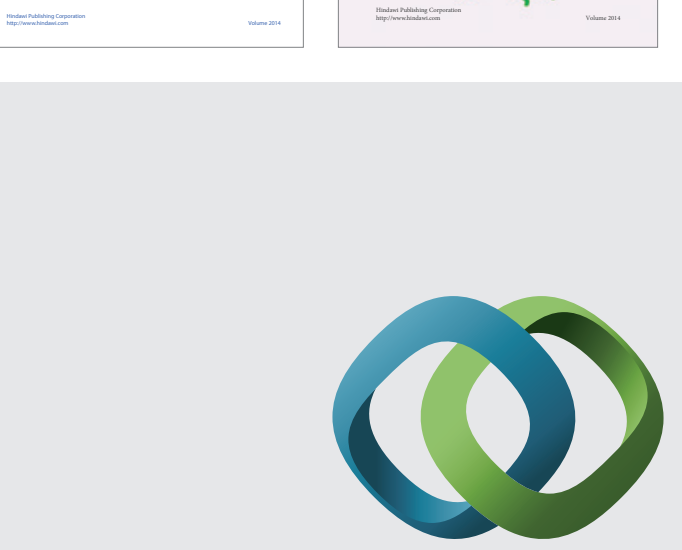

\section{Hindawi}

Submit your manuscripts at

http://www.hindawi.com
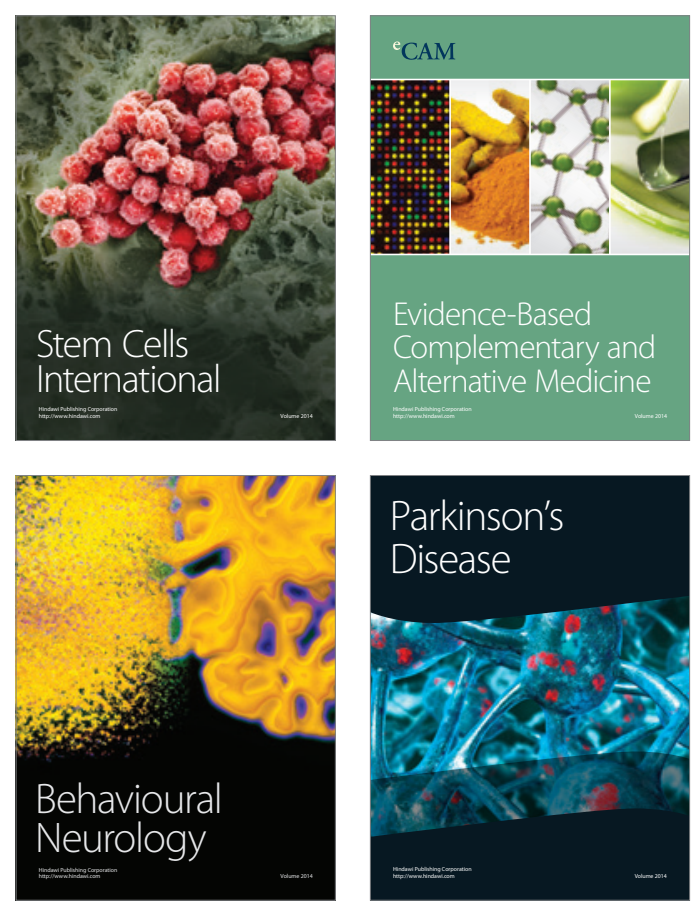

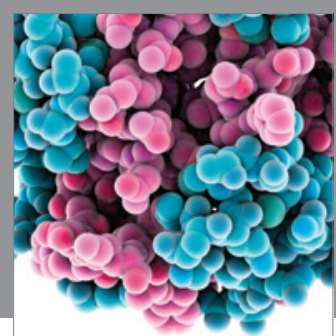

Journal of
Diabetes Research

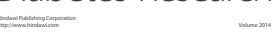

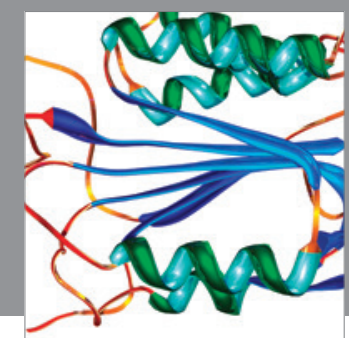

Disease Markers
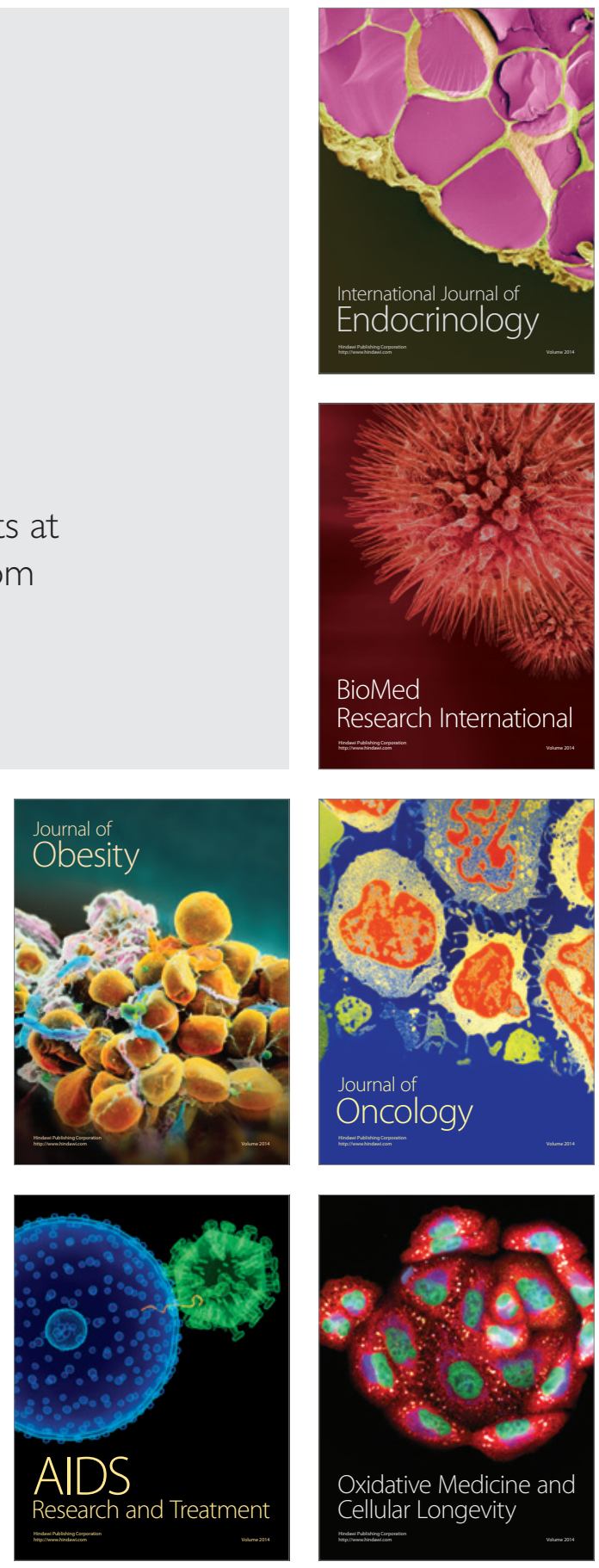